\title{
Prevalence and Characteristics of Smoking among Children under Eighteen Years: About the Investigation in Kabinda's Town, Lomami Province (Democratic Republic of Congo)
}

\author{
Ndjibu Muepu Jacques \\ Department of Nursing, Higher Institute of Medical Techniques of Lubao, Lubao, Democratic Republic of Congo \\ Email: hemanuska@gmail.com
}

How to cite this paper: Jacques, N.M. (2019) Prevalence and Characteristics of Smoking among Children under Eighteen Years: About the Investigation in Kabinda's Town, Lomami Province (Democratic Republic of Congo). Open Access Library Journal, 6: e5521.

https://doi.org/10.4236/oalib.1105521

Received: June 4, 2019

Accepted: July 1, 2019

Published: July 4, 2019

Copyright $\odot 2019$ by author(s) and Open Access Library Inc.

This work is licensed under the Creative Commons Attribution International License (CC BY 4.0).

http://creativecommons.org/licenses/by/4.0/

\section{(c) (i) Open Access}

\begin{abstract}
Background: Smoking is a major public health issue, responsible of high morbidity and mortality. The proportion of tobacco use among teenagers and the early age of initiation to tobacco is a disturbing and unacceptable reality. The aim of this study is to evaluate the prevalence and the characteristics associated with smoking among minors from eight to seventeen years. Methods: We conducted a prospective and descriptive cross-sectional study over a two weeks period, from 18 to 31 May 2014 (Kabinda's town, DR. of Congo). Individuals were interviewed according to the study parameters. The data obtained were analyzed by the software Epi Info 7.1. Results: The smoking prevalence of minors in this study was $20.2 \%$ (304 out of 1506). The profile of the minor smoker was an individual: age of 12 to 17 years, mean age of $14.3 \pm$ 1.5 years, male ( $37.8 \%$ vs. $0.8 \%$ ), illiterate or secondary school, living in an incentive environment with low tobacco mobilization and growing pro-tobacco advertising. The age of the first smoking experience was between 10 and 17 years with a peak at 15 years and a mean age of $14.1 \pm 1$ year. The age between 13 to 17 years $(\mathrm{p}<0.0001)$, male sex $(\mathrm{p}<0.0001)$, and being illiterate or in secondary school $(\mathrm{p}<0.000)$ were associated with the risk of smoking tobacco. Conclusion: It is absolutely necessary to take measures to force the pressure of the tobacco epidemic (factors and context for tobacco use) in children to avoid the harmful consequences of tobacco.
\end{abstract}

\section{Subject Areas}

Public Health

\section{Keywords}

Children, Smoking, Tobacco, Kabinda, DRC 


\section{Introduction}

Tobacco is a tropical plant native to South America of which there are sixty-eight species, the best known being Nicotiana tabacum [1]. Nicotiana tabacum can be used in the form of cigarettes, cigars, pipe or to roll or not to smoke (chewed or chewed). The consumption of these forms, by the non-digestive tract, makes it possible to avoid the destruction of nicotine by the liver after the first-pass effect of the portal vein [2]. Tobacco is a legal drug and smoking is a widespread form of drug abuse worldwide [3] [4] [5]. It is a public health problem [3] [6]. The harmful effects of tobacco on human health have been known for several years [7] [8] after its strong commercialization following the financial gain it generated. The impact of tobacco consumption on the health of the consumer and his immediate environment is not negligible. Tobacco remains the only consumer product that kills its users by a factor of one in two [9] [10] [11]. It is as harmful to the smoker (active smoking) as it is to the non-smoker (passive smoking) [1] [12]. Smoking is responsible for high morbidity (high blood pressure, stroke, erectile dysfunction, polycythemia, abortion, low birth weight, heart and respiratory diseases, cancers, vertebral discopathy, psychoaffective disorders, etc.) [1] [3] [9] and mortality [13] [14]. According to the World Health Organization (WHO 2016) [15], tobacco kills half of its consumers: about 5 to 6 million deaths of which more than $28 \%$ are children and more than $80 \%$ of deaths occur in developing countries (DCs) where there are also more tobacco users [16]. It has been estimated that the trend is expected to increase to 10 million deaths in 2030 [15] [17] [18].

Despite these various misdeeds and the presence of a WHO Global Framework Convention against Tobacco [5] [6], the tobacco industry remains one of the most powerful in the world with very wide degrees of influence [3] [19] [20]. If in the so-called developed countries the awareness of policy makers begins to bear fruit with the decrease in the number of tobacco users [3] [21] [22], it is not the same for the developing countries that are under increasing influence from multinational tobacco companies.

In sub-Saharan Africa, the prevalence of smoking ranged from 1.8\% (Zambia) to $25.8 \%$ (Sierra Leone) in 2014 , with male predominance, although in some countries, such as Rwanda, women smoked more than men [23] [24] [25].

In developing countries, the fight against smoking is generally a slogan. The aggressive promotion of the tobacco industry under a lax climate of political-administrative and health authorities encourages young people to smoke tobacco [3] [26]. The increase in smoking among adolescents and the increasingly early age of initiation [3] [25] are concern for tobacco control organizations. Indeed, child smoking is a disturbing and unacceptable reality since early, consistent and appropriate prevention is possible because of the knowledge of the determinants of smoking in young children in the literature [5] [12] [27].

In the Democratic Republic of Congo (DRC), the general prevalence of smoking in the population remains unknown and studies on smoking are vir- 
tually non-existent, apart from that conducted in Lubumbashi and Kinshasa under external funding as in several countries: Global Youth Tobacco Survey (GYTS) [5] [16] [26]. The GYTS survey found that in the two largest Congolese cities, Lubumbashi and Kinshasa, smoking among school-aged youth was a real epidemic affecting $22.3 \%$ and $24.4 \%$ of young people respectively [5].

The value of this study in Africa in general and DRC in particular is related to the fact that it seems to be the first to address the issue of tobacco use in individuals under 18 and in non-school settings [3] [5] [13]. Including even young people who do not attend school remains a major advantage in assessing the problem of smoking for young children under the age of eighteen (minors according to Congolese legislation) in a global manner.

The objective of this study was to determine the prevalence and characteristics associated with smoking among minors aged eight to seventeen.

\section{Population, Materials and Methods}

\subsection{Site of the Study}

This study was conducted in Shidika (Kabinda town and territory, Lomami province, DR. of Congo). The city of Kabinda, capital of Lomami province, is a decentralized administrative entity, with an estimated population of 295,163 inhabitants (in 2013) spread over sixteen districts, including Shidika. The Shidika was chosen for its heterogeneous distinction of being both one of the neighborhoods at the heart of the city's activities and accommodating almost all categories of the population. It is located northwest of Kabinda City.

\subsection{Type and Population of Study}

This was a cross-sectional descriptive study conducted over a period of two weeks from 18 to 31 May 2014. The study population was that of minors (under 18 according to RD Congolese legislation) aged 8 at 17 and living in the Shidika. The choice of the minimum age of 8 years took into account the fact that at this age the child could express himself better. The sample was random simple. Indeed, the lack of information on the exact number of individuals aged 8 to 17 in the Shidika neighborhood motivated this choice to consider the sample that may come to us during the period of our investigation. To be eligible, children and parents (or guardians) should give their agreement after explanations from the investigators. In a few households, in the absence of parents or guardians, the investigators obtained permission from the (adult) neighbors after the child's informed consent. These explanations concerned the conduct of the interview and the anonymity of the results. The investigators were five, not living in the Shidika neighborhood (to avoid the fear of an adult in the neighborhood in children) and aged 25 to 35 years. They had received prior training for the smooth running of this study. Study parameters included age, sex, level of education (education), reason for smoking, age of first smoking experience, and the elements or activities that motivated the choice of smoking. 


\subsection{Statistical Processing and Analysis of Data}

The data collected from the miners interviewed were entered on the Excel software (Microsoft, USA, 2010) and exported to Epi-Info version 7.1 (Center for Disease Control, Atlanta, USA, 2011). Frequency and average calculations were calculated. The differences observed between the variables studied were assessed using the p-value at the statistically significant threshold $\leq 0.05$.

\subsection{Ethics}

In the absence of an official institution for regulating and monitoring research ethics in the medical sciences, the agreement of the parents and individuals concerned by this study (minors) was obtained. The anonymity and confidentiality of the data had been respected.

\section{Results}

\subsection{General Characteristics of the Respondents}

Table 1 summarizes the characteristics of the minor at risk of smoking by taking into account age, sex and educational attainment. In fact, the profile of the minor smoker at risk was essentially that of the individual over the age of 12, i.e. 13 to 17 years $(\mathrm{n}=302,38.4 \%)$ with an average age of $14.3 \pm 1.5$ years, male $(\mathrm{n}=$ $298,37.8 \%)$, illiterate $(n=91,33.2 \%)$ or high school $(n=177,23.3 \%)$. The statistical difference observed among smokers aged 13 to 17 years and those aged 8 to 12 years $38.4 \%$ vs 0.3 was significant $p<0.0001$. The male sex was significantly ( $\mathrm{p}<0.0001$ ) associated with the smoking status of smokers with $37.8 \%$ vs 0.8 for

Table 1. Sociodemographic characteristics of the respondents.

\begin{tabular}{ccccc}
\hline Characteristics & Total n (\%) & No & Yes & p \\
\cline { 3 - 4 } & & & & \\
Age (years) & $720(100)$ & $718(99.7)$ & $2(0.3)$ & \\
$8-12$ & $786(100)$ & $484(61.6)$ & $302(38.4)$ & 0.0000 \\
$13-17$ & $1506(100)$ & $1202(79.8)$ & $304(20.2)$ & \\
Total & $11.3 \pm 0.1$ & $11.1 \pm 0.2$ & $14.3 \pm 1.5$ & \\
Mean & $8-17$ & $8-17$ & $10-17$ & \\
Extremes & & & & \\
Sex & $789(100)$ & $491(62.2)$ & $298(37.8)$ & \\
Male & $717(100)$ & $711(99.2)$ & $6(0.8)$ & \\
Female & & & & \\
Level of education & & & & \\
Illiterate & $274(100)$ & $183(66.8)$ & $91(33.2)$ & \\
Primary & $471(100)$ & $435(92.4)$ & $36(7.6)$ & 0.00000 \\
Secondary & $761(100)$ & $638(76.7)$ & $177(23.3)$ & \\
\hline
\end{tabular}

${ }^{\star} 1206$ currently enrolled, or $80.1 \%$. 
females.

In this study, level of education was significantly associated $(\mathrm{p}<0.000)$ with the risk of smoking: being an illiterate child (33.2\%), attending high school (23.3\%) and primary school (7.6\%) predisposes to being a smoker.

\subsection{Prevalence of Smoking and Related Factors}

Of the 2062 juveniles surveyed during the period of our survey, 1506 (73.0\%) aged 8 to 17 were selected for our survey. The prevalence of smoking among these eight to seventeen year olds was $20.2 \%$, or 304 out of 1506 . The vast majority of the minors involved were between the ages of 13 and 17 ( $n=786$ out of $1506,52.3 \%$ ). The average age was $11.3 \pm 0.1$ years with extremes ranging from 8 to 17 years. Boys were the most represented with $53.4 \%(n=789$ out of 1506) and $46.6 \%$ for girls ( $n=717$ out of 1506). The sex ratio was 1.1 in favor of the male sex. In this study, $80.1 \%(\mathrm{n}=1206)$ of the minors interviewed were in school and most of these minors had either been to primary school $(\mathrm{n}=471$, $31.3 \%)$ or high school $(\mathrm{n}=761,50.5 \%)$. The proportion of illiterates among these children was 274 out of 1506 (18.2\%) (Table 1).

\subsection{Characteristics of Smoking among the Minors Surveyed}

\subsubsection{Age of Onset of Smoking}

According to Table 2, the average age of onset of smoking was $14.1 \pm 1$ years with extremes ranging from 10 to 17 years. The majority of minors started smoking at the age of $15(\mathrm{n}=82,27.0 \%)$ followed by those at $13(\mathrm{n}=72,13.8 \%)$ and $14(\mathrm{n}=64,1 \%)$.

\subsubsection{Reasons Motivating Minors to Smoke}

With respect to Figure 1, the main reasons for smoking were listed in descending order: influenza and/or cough $(\mathrm{n}=235,77.3 \%)$, pleasure of smoking $(\mathrm{n}=$ 192; 63.2\%), the desire to awaken one's mind $(\mathrm{n}=159,52.3 \%)$ and the fight against the cold ( $n=72,23.7 \%)$.

Table 2. Age of first experience of smoking.

\begin{tabular}{ccc}
\hline Age (years)* & n & $\%$ \\
\hline 10 & 1 & 0.3 \\
11 & 1 & 0.3 \\
12 & 42 & 13.8 \\
13 & 72 & 23.7 \\
14 & 64 & 21.1 \\
15 & 82 & 27.0 \\
16 & 24 & 7.9 \\
17 & 18 & 5.9 \\
Total & 304 & 100 \\
\hline
\end{tabular}

${ }^{\star}$ Means age $14.1 \pm 1$ year. 


\section{Factors influencing smoking among minors}

In our study (Table 3), it was found that attending a group of smoking friends (46.5\% vs $4.5 \mathrm{p}<0.0001)$, having parents who smoked $(27.5 \%$ vs $14.0 \mathrm{p}<$ $0.0001)$, sell cigarettes $(42.5 \%$ vs $13.3 \mathrm{p}<0.0001)$, be sent to buy cigarettes $(60.5 \%$ vs $12.2 \mathrm{p}<0.0001)$, live in the same plot with adult smokers $(24.0 \%$ vs $17.6 ; \mathrm{p}=0.003)$ and light cigarettes for an adult $(27.3 \%$ vs $18.5 ; \mathrm{p}=0.001)$ had significantly influenced minors to smoke tobacco.

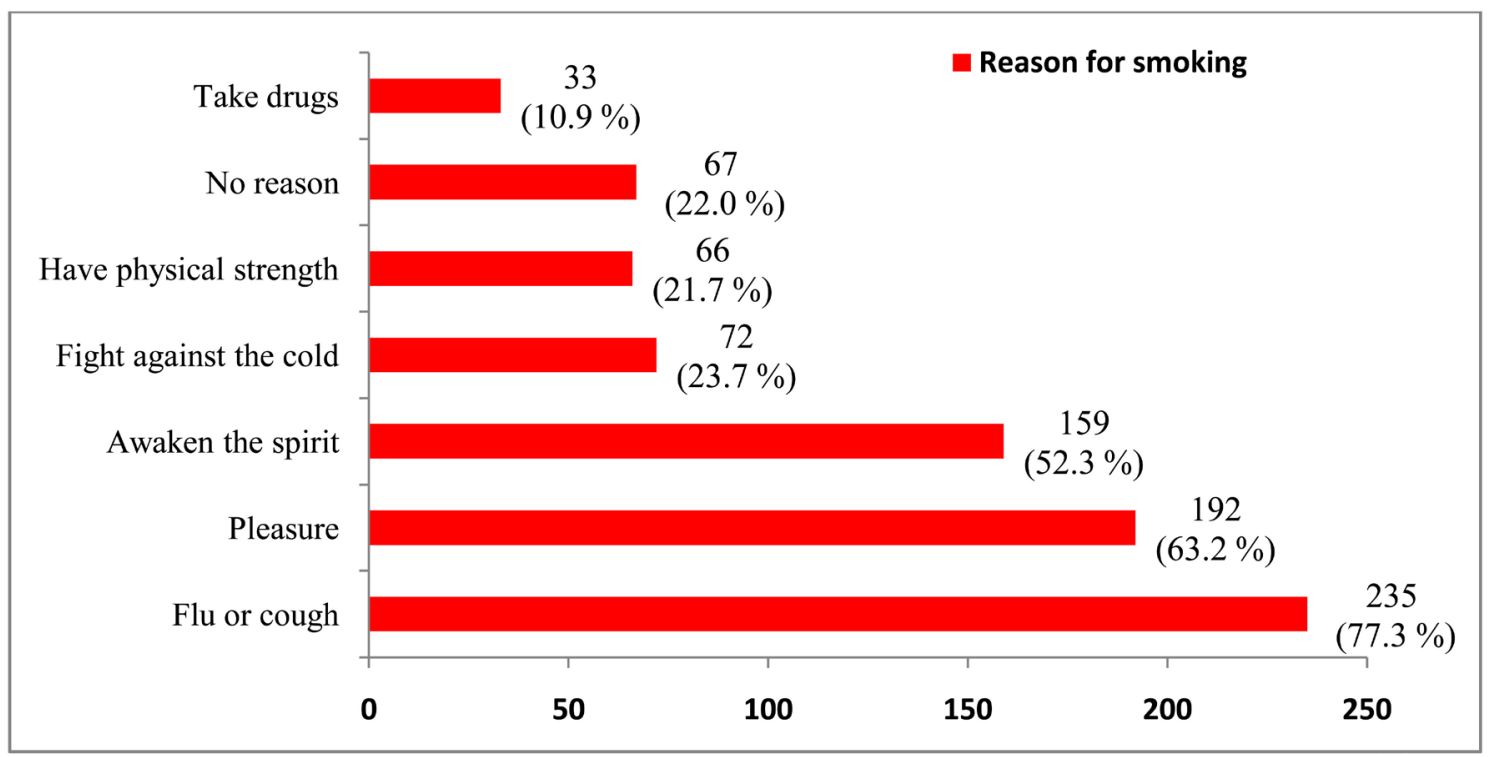

Figure 1. Principals reason for smoking among respondents $(\mathrm{n}=304)$.

Table 3. Factors influencing minors to smoke

\begin{tabular}{|c|c|c|c|c|c|}
\hline \multirow{2}{*}{ Influencing factors } & & \multicolumn{4}{|c|}{ Smokers } \\
\hline & & Total & No & Yes & \\
\hline \multirow{2}{*}{ Parents who smoke } & Yes & $691(100)$ & $501(72.5)$ & $190(27.5)$ & \multirow{2}{*}{0.000} \\
\hline & No & 815 (100) & 701 (86.0) & $114(14.0)$ & \\
\hline \multirow{2}{*}{ Have groups of friends who smoke } & Yes & $564(100)$ & $302(53.5)$ & $262(46.5)$ & \multirow[b]{2}{*}{0.000} \\
\hline & No & $942(100)$ & 900 (95.5) & $42(4.5)$ & \\
\hline \multirow[b]{2}{*}{ Habit to be sent to buy the cigarette } & Yes & $248(100)$ & $98(39.5)$ & $150(60.5)$ & \multirow[b]{2}{*}{0.000} \\
\hline & No & $1258(100)$ & $1104(87.8)$ & $154(12.2)$ & \\
\hline \multirow{2}{*}{ Habit to be sent to light the cigarette } & Yes & $293(100)$ & $213(72.7)$ & $80(27.3)$ & \multirow[b]{2}{*}{0.001} \\
\hline & No & $1213(100)$ & $989(81.5)$ & $224(18.5)$ & \\
\hline \multirow[b]{2}{*}{ Sell the cigarette } & Yes & $355(100)$ & $204(57.5)$ & $151(42.5)$ & \multirow[b]{2}{*}{0.000} \\
\hline & No & $1151(100)$ & 998 (86.7) & $153(13.3)$ & \\
\hline \multirow{2}{*}{ Living with smokers in the plot } & Yes & $617(100)$ & $469(76.0)$ & $148(24.0)$ & \multirow{2}{*}{0.003} \\
\hline & No & $889(100)$ & $733(82.4)$ & $156(17.6)$ & \\
\hline
\end{tabular}




\section{Discussion}

Tobacco use in the world is not recent. It derives from the discovery of the American continent at the end of the $15^{\text {th }}$ century by the navigator Christoph Colombus [12] [15]. Like alcohol, the use of tobacco in different societies has found its way across all socioeconomic classes [12]. In tobacco smoke there are several toxic substances that combine [1]: Nicotine, Urethane, Ammonia, Hydrogen cyanide, Toluene, Acetone, Naphthalene, methanol, Pyrene, Naphthalene, Cadmium, Carbon monoxide, Vinyl chloride, Arsenic, Polonium 210, DDT, etc.

The harmfulness of tobacco has been known for several years but it seems that the will to fight effectively against smoking is lower than expected. The majority of politico-administrative decision-makers put economic interests ahead of health interests, while the consequences of tobacco consumption can, per cycle, result in more financial resources allocated to health. That is, the financial gains from tobacco taxes cannot cover the health consequences of smoking. The objective of this study was to determine the prevalence and characteristics associated with smoking among children aged eight to seventeen.

\subsection{Frequency of Smoking and General Characteristics of the Respondents}

In this study, which focused on tobacco use among minors aged 8 to 17 years in the DRC town of Kabinda, the prevalence of smoking was $20.2 \%$. It seems to be very high to constitute a major health problem with regard to the risks incurred by young people [5] [6] [15]. But the prevalence close to ours had been mentioned in the various GYTS studies in Africa: Lubumbashi and Kinshasa in the DRC with respectively $24.4 \%$ and $22.3 \%$ among the students [5]; $22.9 \%$ in schools in the People's Republic of Congo [26]; and 22 to 23\% reported in Ouagadougou and Bobo Dioulasso in Burkina Faso [16].

On the other hand, in the Bamako school in Mali among pupils aged between 12 and 23, 47.6\% of students had smoked at least once and 14\% were regular smokers, including $100 \%$ of boys [13].

These different results of African studies demonstrate the risks faced by young people and the need to strengthen anti-smoking measures in Africa. However, it is important to note that unlike the above studies [5] [13] [16] [26], our study series has certain peculiarities: study in non-school environment and concerns only minors aged 8 to 17 years old. Indeed, the fact of conducting such studies in schools would present a weakness in the conditions of low attendance at school: what we had avoided in our environment where the rate of illiteracy remains quite high. For Bogui et al. [25] in school and student in Abidjan (Côte d'Ivoire) from 8 to 22 years, the prevalence of smoking was less than $10 \%$ and increased with age.

Similarly, the characteristics of the respondents in this study differ from all the studies we had met on smoking. Indeed, our study seems to be the first that 
specifically targets minors aged 8 to 17 years. The vast majority of children were aged 13 to 17 years (52.3\%) with an average age of $11.3 \pm 0.1$ years. Boys were the most met compared to girls ( $53.4 \%$ vs. $46.6 \%)$.

Most of the minors studied were in school (80.1\%) and in $18.2 \%$ of cases minors were illiterate. There is a need for more studies on smoking in Congolese settings to have a national prevalence. We believe that the prevalence of smokers among children is closely related to that of adults and the level of modernity.

\subsection{Characteristics of Smoking among the Minors Surveyed}

\subsubsection{Sociodemographic Profile: Age, Sex, Level of Education and Smoking}

In this study, the age of 13 to 17 years $(p=0.000)$, the male sex $(p=0.000)$ and the fact of being illiterate or of secondary education $(p=0.000)$ were associated with the risk of smoking tobacco among minors. The comparison of our results with some studies [5] [13] [26] is problematic at this point because of the different methodological approaches. However, many scientific studies recognize the risk for boys compared to girls [5] [23] [28] [29], even though there is a phenomenon of feminization of smoking [24] [30] [31].

In our environment, the greater exposure of boys can be explained by the high degree of freedom they enjoy compared to girls. The latter are often next to their mothers to assist them with housework [18]. Illiteracy is a hindrance to some information that would easily be obtained at school. In this study, illiterate minors were the largest smokers compared to those who attended school [32]. It is therefore necessary to strengthen the access of all young people to studies. Koueta et al. [18] in Ouagadougou had also mentioned the affluent economic conditions as a factor favoring smoking. This aspect had not been addressed in our study.

\section{Age of start of smoking}

The influence of tobacco industries among young people is growing and the age of first experience of tobacco consumption has become increasingly precocious [3] [5] [18]. In this study for children aged 8 to 17, the age of onset of smoking was $14.1 \pm 1$ year with extremes of 10 to 17 years. The majority of minors started smoking at age 15 (27\%), followed by those aged 13,14,12, 16 and 17 (Table 2). This study reveals that it was rare to smoke before age 12 and that the 12 to 16 age group remains more exposed to the high risk of smoking. The average age of initiation of smoking in this study is close to the results in Africa [18] [20] [25] and France [30] [31]. In the GYTS studies in Burkina Faso [16] and the DRC [5], the age of first experience of smoking was lower than ours and was around seven years. These various results testify to the need for the early establishment of appropriate preventive measures against smoking for children.

\section{Reasons given to justify smoking among minors}

The main reasons for minors smoking have been appreciated by several authors and appear to be the same with small variations given the study methodology used [3] [13] [21] [25]. In descending order, the youth of Kabinda evoked the flu and/or cough, the pleasure of smoking, the desire to awaken one's 
mind, the fight against the cold, the possibility of having the physical strength and the deliberate will to take drugs without any reason. As can be seen, these results reflect the lack of quality information on tobacco and its risks among children. Efforts should be made in the youth leadership to provide reliable and quality information that can help him overcome any attempt to smoke due to false reasons or information.

\subsubsection{Factors Influencing Smoking among Minors Studied}

Everyday experiences and personal needs shape the intentions and actions of every person [12]. It's the same for young people. In this study, the miners referred to several factors that would have influenced them to consume tobacco. This was in decreasing order of attendance of groups of smoking friends, having parents who smoked, the habit of selling tobacco, the habit of sending young people to buy cigarettes, the fact of live with neighbors smokers and the habit of sending young people to light the cigarette. These different arguments had also been mentioned by several authors in the literature [3] [33] [34]. It turns out that the incentive environment is at the base of tobacco consumption among minors. It is often said that "children often like to copy what adults do".

To these factors described in this study, Anderson [12] adds knowledge of at least one cigarette brand and positive belief in tobacco. Sangho et al. [13] in Mali also mentioned having a smoking teacher.

As we can see in our environment, no minor had mentioned the role of the media, as pointed out in some studies [3] [18] [35]. Indeed, the place of audiovisual media in the mobilization of the masses and in particular young children remains unavoidable. But in our milieu, this power is diminished by the discontinuous broadcast of broadcast channels and the low interest accorded to these local channels by young people. Television almost depends on channels that broadcast on satellite, which many families cannot afford. There is also the significant part of video films (where people smoke) in cinemas screened on the run without any regulations. In our study, this source was not primarily mentioned by the minors concerned.

Given the results of this study, it is important to fight against modifiable factors mentioned by minors. The development and implementation of preventive programs requires consideration of the different influences that motivate young people to smoke [3] [5] [33] [36]. The absence of firm and youth-specific legislation and non-compliance with legal texts related to the production, distribution, marketing and consumption of cigarettes and other tobacco products in the DRC would play a key role plan in the high prevalence of young smokers, as highlighted by the different studies [3] [5] [26].

Politico-administrative and health authorities should visibly make tobacco control a national priority by strengthening and enforcing national legislation (such as Ministerial Order No. 008/CAB./MIN. INFO. PRES. \& COM.NAT./2007 of 09 July 2007 setting the criteria for the assessment of advertising on tobacco and alcoholic beverages, in particular point 7-C3 of Article 7 on tasting prohibited to 
under-18s) [37] and the WHO Framework Convention on Tobacco Control [6] that the DRC had ratified on 25 October 2005 [5]. As we can see, the DRC often suffers from problems related to the application of legal texts: everywhere in the country in general and the city of Kabinda in particular, you can buy tobacco products anywhere, anytime and anywhere in anyone.

In the DRC, mobilization against tobacco remains low. Studies on smoking are very rare and often dependent on external funding while there is a whole national program (PNLCT) that should be supported, primarily by the funds of the Republic. The fight against smoking in the general population and young people in particular requires several studies related to the exact production and sale on the one hand and on the other hand surveys in the population.

The following measures significantly reduce the influence of the tobacco and tobacco industries: regular increases in tobacco prices, mass campaigns (carnivals) and audiovisual (television and radio channels) to the detriment of the consumption of tobacco products, conferences on the harmful effects of tobacco, the ban on smoking in public, the strengthening of anti-smoking legislation and the support of health personnel in smoking cessation [18] [21] [22] [38] [39].

In Kabinda, the price of a pack of cigarettes varies according to brands from 0.4 to 0.5 US dollars (USD) and the sale is even carried out in detail by cigarette stems ( 1 cigarette less than 0.08 USD). This low price is favorable to the purchase by minors.

Training of health personnel in smoking cessation is therefore necessary because many smokers often want to stop smoking but cannot [27] [40] by lack of knowledge of effective withdrawal techniques. The training of general practitioners in the effective support of smokers during weaning had given good results in France [38]. The use of electronic cigarettes (E-cigarettes) cannot be an alternative since even in countries where its use is permitted (Europe, America, etc.) there is a danger for young people [41].

In the context of this study, a team of child psychiatrist, psychologist, pediatrician and sociologist seems to be necessary for the management of problems related to smoking of the child. But unfortunately, it is rare to see these initiatives in our African countries.

\section{Limitations of this study}

The lack of funding and the ages chosen for this study did not allow having some information sought. Thus, information such as knowledge of tobacco laws, the number of cigarettes consumed per day, the judgment of the harmfulness of tobacco, advertising on tobacco, etc. have not been addressed in this study. Similarly, it would have been preferable to extend this work to the entire city of Kabinda and to correlate the prevalence of smokers with the number of packets or cartons of cigarettes sold by the representations of tobacco companies. We leave these fields of investigation to subsequent studies. Nevertheless, the information provided by this study remains very relevant to anyone who is interested in tobacco and adolescent health. 
We dare to believe that they will: guide the program for the fight against drug addiction and the subsequent studies on smoking in our environment; and to sensitize the global community on the danger of tobacco in the near future and the need to undertake in-depth studies on child smoking by the scientific community.

\section{Conclusions}

Tobacco use is one of the preventable causes of morbidity and mortality worldwide. In Kabinda, tobacco consumption among minors (20.2\%) is a veritable epidemic fueled by the incentive environment, and the absence of a manifest and strong political and administrative will discourage the constant evolution of tobacco consumption by the respect of the existing regulations, the weakness of the specific legislation anti-tobacco and the not effective framing of the youth.

The age of 13 to 17 years, the male gender, and being illiterate or at the high school level were associated with the risk of smoking tobacco.

To effectively combat the increase in the dynamism of tobacco consumption observed in this study and in the world, we recommend the following measures in connection with our socio-cultural conditions: to strengthen the education of minors, create a commission to fight against youth smoking, enhance and enforce smoke-free legislation, strengthen public awareness campaigns about the harmful effects of active and passive smoking, fund the national addictions and toxic substances program to make it more visible (PNLCT), ban smoking in public, train health staff in smoking cessation techniques, fund smoking studies, include and teach about the harmful effects of tobacco in the first year of primary school, create youth groups for reflection, psycho-emotional support and tobacco control, raise taxes on tobacco.

It should be noted, however, that these measures cannot be carried out without the political will. It can be based on the misdeeds of tobacco recognized by the scientific community and the tobacco industries themselves.

\section{Acknowledgements}

We would like to thank KIMPITU KIFWAME P. and Dr. H. KABEMBA BUKASA for their contributions in collecting data and reading for formatting this article.

\section{Conflicts of Interest}

No conflict of interest was noted with respect to this study.

\section{References}

[1] Ndibe, F. (2012) Evaluation du niveau de connaissance sur les dangers liés au tabagisme chez les jeunes (cas des jeunes fumeurs de 17 à 30 ans de la commune de Tshopo en RDC). Mémoire de Licence en santé publique, Université de Kisangani, Kisangani, $42 \mathrm{p}$.

[2] Benowitz, N.L., Jacob, P. and Savanapridi, C. (1987) Determinants of Nicotine In- 
take While Chewing Nicotine Polyacrilex Gum. Clinical Pharmacology and Therapeutics, 41, 467-473. https://doi.org/10.1038/clpt.1987.58

[3] Ouédraogo, A., Ouédraogo, T.L., Ouoba, D.E. and Sawadogo, J.P. (2000) Situation actuelle du tabagisme au Burkina Faso: Données globales sur l'offre et enquête CAPC auprès des jeunes de la ville de Ouagadougou. Cahiers détudes et de recherches francophones/ Santé, 10, 177-181.

[4] Flaudias, V., Picot, M.C., Lopez-Castroman, J., Llorca, P.-M., Schmitt, A., Perriot, J., et al. (2016) Executive Functions in Tobacco Dependence: Importance of Inhibitory Capacities. PLoS ONE, 11, e0150940. https://doi.org/10.1371/journal.pone.0150940

[5] Programme national de lutte contre les toxicomanies et les substances toxiques (PNLCT)/RDC (2008) Le tabagisme en milieu scolaire en République Démocratique du Congo: Rapport de l'enquête globale GYTS sur le tabagisme chez les jeunes, 9 p.

[6] Organisation Mondiale de la santé (2005) Convention-Cadre de l'OMS pour la lutte antitabac. LC/NLM-HD 9130.6, $37 \mathrm{p}$.

[7] Guilbert, P., Gautier, A., Beck, F., Peretti-Watel, P., Wilquin, J.-L., Léon, C., et al. (2005) Tabagisme: Estimation de la prévalence déclarée, Baromètre santé, France, 2004-2005. Bulletin Epidémiologique Hebdomadaire, No. 21-22, 97-98.

[8] Hill, C. (2012) Epidémiologie du tabagisme. La Revue du praticien, 62, 325-329.

[9] Dautzenberg, B., Dureuil, B., Trosini-Désert, V. and Jacques Masquelet, A. (2006) Le défi de la prise en charge du tabagisme péri-opératoire. Bulletin Epidémiologique Hebdomadaire, No. 21-22, 142-145.

[10] Xu, Y., Xu, S., Wu, Q. and Guo, Y. (2013) Tobacco Knowledge among Adults in Zhejiang Province, China. PLoS ONE, 8, e59172.

https://doi.org/10.1371/journal.pone.0059172

[11] Elmasry, S., Asfour, S., De Rivero Vaccari, J.P. and Travascio, F. (2015) Effects of Tobacco Smoking on the Degeneration of the Intervertebral Disc: A Finite Element Study. PLoS ONE, 10, e0136137. https://doi.org/10.1371/journal.pone.0136137

[12] Anderson, K. (1997) Les jeunes, l'alcool, la drogue et le tabac. Publications OMS-Europe, LCHV 5135, No. 66, 22 p.

[13] Sangho, H., Keita Sidibé, A., Kodio, A., Tayeb Mint, M., Keita Dembélé, H., Cissé Oumar, M., et al. (2004) Tabagisme en milieu scolaire dans une commune de Bamako au Mali. Mali Medical, 29, 36-39.

[14] Gaete, J., Ortuzan, C., Zitko, P., Montgomery, A. and Araya, R. (2016) Influence of School-Related Factors on Smoking among Chilean Adolescents: A Cross-Sectional Multilevel Study. BMC Pediatrics, 16, 79.

https://doi.org/10.1186/s12887-016-0612-Z

[15] OMS (2016) Tabagisme. Aide-mémoire No 339.

[16] Ezzati, M. and Lopez, A.D. (2003) Estimates of Global Mortality Attributable to Smoking. The Lancet, 362, 847-852. https://doi.org/10.1016/S0140-6736(03)14338-3

[17] Association Burkinabe de santé publique (ABSP) (2003) Enquête sur le tabac chez les adolescents en milieu scolaire de Ouagadougou et de Bobo Dioulasso au Burkina Faso: Rapport global sur l'enquête GYTS 2001, 24 p.

[18] Koueta, F., Dao, L., Yé, D., Koura, M. and Sawadogo, A. (2009) Facteurs favorisants le tabagisme des élèves à Ouagadougou (Burkina Faso). Revue des Maladies Respiratoires, 26, 291-297. https://doi.org/10.1016/S0761-8425(09)72586-0

[19] Wang, F., Zheng, P., Yang, D., Freeman, B., Fu, H. and Chapman, S. (2014) Chinese Tobacco Industry Promotional Activity on the Microblog Weibo. PLoS ONE, 9, e99336. https://doi.org/10.1371/journal.pone.0099336 
[20] Savell, E., Gilmore, A.B. and Fooks, G. (2014) How Does the Tobacco Industry Attempt to Influence Marketing Regulations? A Systematic Review. PLoS ONE, 9, e87389. https://doi.org/10.1371/journal.pone.0087389

[21] Chaloupka, F.J., Straif, K. and Leon, M.E. (2010) Effectiveness of Tax and Price Policies in Tobacco Control. Tobacco Control, 20, 235-238. https://doi.org/10.1136/tc.2010.039982

[22] Beck, F., Legleye, S. and Spilka, S. (2005) Baisse du tabagisme parmi les adolescents: Principaux résultats de l'enquête Escapad, France 2003. Bulletin Epidémiologique Hebdomadaire, 21-22, 99-102.

[23] Brathwaite, R., Addo, J., Smeeth, L. and Lock, K. (2015) A Systematic Review of Tobacco Smoking Prevalence and Description of Tobacco Control Strategies in Sub-Saharan African Countries; 2007 to 2014. PLOS ONE, 10, e0132401. https://doi.org/10.1371/journal.pone.0132401

[24] Hill, C. and Laplanche, A. (2005) Évolution de la consommation de cigarettes en France par sexe, 1900-2003. Bulletin Epidémiologique Hebdomadaire, No. 21-22, 94-97.

[25] Bogui, P., Yessoh, M., Tuo, N., Ouattara, S., Da, H.C. and Kouamé, N. (2004) Tabagisme des élèves et étudiants âgés de 8 à 22 ans à Abidjan en 2002. Revue des Maladies Respiratoires, 21, 693-703. https://doi.org/10.1016/S0761-8425(04)71410-2

[26] Ministère de la santé, des affaires sociales et de la famille/Congo (2007) Rapport de l'enquête globale sur le tabagisme chez les jeunes de 13 à 15 ans en milieu scolaire, République du Congo, $57 \mathrm{p}$.

[27] McKay, A.J., Patel, R.K.K. and Majeed, A. (2015) Strategies for Tobacco Control in India: A Systematic Review. PLoS ONE, 10, e0122610. https://doi.org/10.1371/journal.pone.0122610

[28] Rakotomizao, J., Rakotoarimanana, S., Andriamihajas, S. and Andrianarisoa, A. (2004) 225 Place du tabagisme de l'entourage dans le tabagisme scolaire. Revue des Maladies Respiratoires, 21, 85-88. https://doi.org/10.1016/S0761-8425(04)71851-3

[29] Kouassi, B.A., Horo, K., Nigué, L., Kassi, O., Ahui, B.J.M., Koffi, N., Ngom, A. and Aka-Danguy, E. (2007) Tabagisme en milieu scolaire dans le commune de Coccody à Abidjan. Revue de Pneumologie Clinique, 63, 35-39. https://doi.org/10.1016/S0761-8417(07)90087-5

[30] Martinet, Y. (2002) Le défi du tabagisme des adolescentes. Revue des Maladies Respiratoires, 19, 285-287.

[31] Saadjian, M., Gouitaa, M., Lanteaume, A., Ramadour, M., Vervolet, D. and Charpin, D. (2002) Facteurs associés au tabagisme en classe de sixième. Revue des Maladies Respiratoires, 19, 431-434.

[32] Gaete, J. and Araya, R. (2017) Individual and Contextual Factors Associated with Tobacco, Alcohol, and Cannabis Use among Chilean Adolescents: A Multilevel Study. Journal of Adolescence, 56, 166-178. https://doi.org/10.1016/j.adolescence.2017.02.011

[33] Strong, D.R., Messer, K., Hartman, S.J., Nodora, J., Vera, L. and White, M.M. (2017) Pre-Adolescent Receptivity to Tobacco Marketing and Its Relationship to Acquiring Friends Who Smoke and Cigarette Smoking Initiation. Annals of Behavioral Medicine, 51, 730-740. https://doi.org/10.1007/s12160-017-9896-y

[34] Sondo, B., Testa, J. and Soura, Y. (1996) Tabagisme des élèves des établissements secondaires du Burkina Faso. Revue des Maladies Respiratoires, 13, 493-497. 
[35] Achia, T.N.O. (2015) Tobacco Use and Mass Media Utilization in Sub-Saharan Africa. PLoS ONE, 10, e0117219. https://doi.org/10.1371/journal.pone.0117219

[36] Diallo, S., Tchuindem, S., M’baye, O., Sissoko, B., Kayantao, D. and Dao, S. (2004) Le tabagisme chez les Lycéens dans le district de Bamako. Mali Médical, 34, 32-34.

[37] RDC (2007) Arrêté Ministériel No. 008/CAB./MIN. INFO. PRES. \& COM. NAT./2007 du 09 Juillet 2007 fixant les critères d'appréciation de la publicité sur le tabac et les boissons alcoolisées [DRC/Ministerial Order No. 008/CAB./MIN. INFO. NEAR. \& COM. NAT./2007 of 09 July 2007 Setting the Criteria for the Evaluation of Advertising on Tobacco and Alcoholic Beverages].

[38] Stoebner-Delbarre, A., Letourmy, F. and Sancho-Garnier, H. (2005) Rôles et actions efficaces des médecins généralistes dans le sevrage tabagique. Bulletin Epidémiologique Hebdomadaire, 21-22, 103-105.

[39] John, R.M., Sung, H.Y. and Max, W. (2009) Economic Cost of Tobacco Use in India, 2004. Tobacco Control, 18, 138-143. https://doi.org/10.1136/tc.2008.027466

[40] Sargent, J.D., Mott, L.A. and Stevens, M. (1998) Predictors of Smoking Cessation in Adolescents. Archives of Pediatrics and Adolescence Medicine Journal, 152, 388-393. https://doi.org/10.1001/archpedi.152.4.388

[41] Dautzenberg, B., Birkui, P., Noël, M., Dorsett, J., Osman, M. and Dautzenberg, M.-D. (2013) E-Cigarette: A New Tobacco Product for Schoolchildren in Paris. Open Journal of Respiratory Diseases, 3, 21-24.

https://doi.org/10.4236/ojrd.2013.31004 